\title{
Identification of a Lobe in the Adult Human Pancreas Rich in Pancreatic Polypeptide
}

\author{
F. Malaisse-Lagae, Y. Stefan, J. Cox ${ }^{1}$, A. Perrelet, and L. Orci \\ Institute of Histology and Embryology, and ${ }^{1}$ Department of Pathology, University of Geneva, Geneva, Switzerland
}

\begin{abstract}
Summary. Systematic sampling of human necropsy pancreases has revealed that pancreatic polypeptide (PP) cells are not distributed equally in the gland. PP-cells are the most abundant cell type in the posterior part of the pancreatic head while they are scarce or absent in the remainder of the gland. The PP-rich part of the head can be separated by blunt dissection from the pancreas as a discrete lobe. This lobe probably originates from the ventral pancreatic bud during embryogenesis. A quantitative study of the immunofluorescent endocrine cell types (insulin, glucagon, somatostatin and pancreatic polypeptide cells) in PP-rich and PP-poor regions of pancreases in 8 subjects with ages ranging from 33 fetal weeks to 80 years, showed that the proportions of the cell types were different in youngs and adults.
\end{abstract}

Key words: Pancreas, islets of Langerhans, insulin, glucagon, somatostatin, pancreatic polypeptide, immunohistochemistry, embryology.

The mammalian endocrine pancreas (islets of Langerhans) contains four well-established secretory cell types: insulin, glucagon, somatostatin and the more recently discovered pancreatic polypeptidecontaining cells [1]. Following the discovery of nonhomogeneity in islet cell populations in the normal rodent pancreas $[2,3]$ and the report of variations of the number of pancreatic polypeptide cells in cases of juvenile diabetes [4] and pancreatitis [5], we have systematically re-evaluated the distribution of endocrine cells in human islets of Langerhans.

\section{Material and Methods}

Pancreases obtained at necropsy were studied. The ages of the subjects ranged from 33 fetal weeks to 87 years. The post-mortem diagnoses are shown in Table 1 . In none of the cases, was involvment of the pancreas in the disease process suspected.
Necropsy was performed within 4 to 20 hours following death After cleaning in situ, from the surrounding organs and adhering tissues, the anterior surface of the pancreas was painted with an India ink-latex mixture to allow proper orientation of the pancreatic samples after removal from the body. The pancreas was cut into 8 successive portions (Fig. 1) [6]: I: uncinate process; II: lower part of the head; III: middle part of the head; IV: upper part of the head; V: neck or isthmus; VI: body 1; VII: body 2; VIII: tail. The volume of each portion was determined according to Archimedes' principle by immersion in a graduated cylinder half-filled with $0.154 \mathrm{~mol} / 1$ saline. In each of the 8 portions, at least one $5 \mathrm{~mm}$ thick slice (horizontal in the head, vertical in the body and tail) was fixed in Bouin's fluid, the left side of each horizontal slice and the inferior side of each vertical slice being further marked by an incision made with the scalpel. After $20 \mathrm{~h}$. fixation, the $5 \mathrm{~mm}$ slices were dehydrated and embedded in paraffin. $5 \mu \mathrm{m}$ sections were then cut from the blocks and stained by indirect immunofluorescence [7] with the following antisera: anti-insulin (Dr. P.H. Wright, Indianapolis), anti-glucagon (Dr. R. A. Donald, Christchurch, New Zealand), anti-somatostatin (Dr. S. Ito, Niigata, Japan) and anti-pancreatic polypeptide antisera (Dr. R. E. Chance, Indianapolis, USA). The specificity of the antisera had been established radioimmunologically by the respective donors. Dilutions were respectively $1 / 200 ; 1 / 100 ; 1 / 200$; and $1 /$ 100. The morphological identification of the cell-bound antiserum was done with a commercially-available anti-rabbit (anti-somatostatin, anti-glucagon, and anti-pancreatic polypeptide) or antiguinea pig (anti-insulin) $\gamma$ globulin antiserum coupled to fluorescein isothiocyanate (Pasteur Institute, Paris). In addition, some pieces of tissue were studied with the immunostaining method using peroxidase-anti peroxidase antiserum to reveal the specific antihormone antisera [8]. Control of the staining specificity was carried out by incubating the sections with the respective antisera, each previously absorbed with its homologous antigen. No staining was obtained in these conditions.

\section{Results}

Groups of pancreatic polypeptide-rich lobules were found in all cases in the head of the pancreas (regions I-IV), but never in the body and tail of the organ (regions V-VIII) (see Fig. 1). In the latter regions, only scattered fluorescent cells were observed in some islets. By contrast, in PP-rich lobules of the pancreatic head, PP-cells were more frequent than any of the other endocrine cell types studied (Table 2). 
Table 1

\begin{tabular}{|c|c|c|c|}
\hline Case no & Age & Sex & $\begin{array}{l}\text { Characteristics of subjects from whom } \\
\text { pancreases were removed }\end{array}$ \\
\hline 1 & foetus $24 \mathrm{w}$ & $\mathrm{F}$ & Premature stillborn \\
\hline 2 & foetus $24 w$ & $\mathrm{M}$ & Premature stillborn \\
\hline 3 & foetus $33 w$ & $\mathbf{M}$ & Premature stillborn \\
\hline 4 & $2 \mathrm{~d}$ & $\mathrm{M}$ & Cardiac malformation \\
\hline 5 & $3 w$ & M & Cardiac malformation, pneumonitis \\
\hline 6 & $5 \mathrm{~m}$ & $\mathrm{~F}$ & Crib death \\
\hline 7 & $9 y$ & $\mathrm{~F}$ & Cardiac malformation, ileitis ${ }^{c}$ \\
\hline 8 & $25 y$ & $\mathrm{M}$ & Multiple trauma, brain injury \\
\hline 9 & $29 y$ & $\mathbf{M}$ & Myocardial infarction \\
\hline 10 & $44 y$ & $\mathrm{~F}$ & Sub-arachnoid haemorrhage \\
\hline 11 & $45 y$ & $\mathrm{M}$ & Liver cirrhosis \\
\hline 12 & $46 y$ & $\mathrm{~F}$ & Liver cirrhosis, intestinal haemorrhage \\
\hline 13 & $48 y$ & M & Metastatic bronchial carcinoma \\
\hline 14 & $51 \mathrm{y}$ & M & Alcoholic cardiomyopathy, lung infarction \\
\hline 15 & $53 y$ & M & Mitral valve insufficiency, liver cirrhosis ${ }^{\mathrm{c}}$ \\
\hline 16 & $54 \mathrm{y}$ & M & Myocardial infarction ${ }^{\mathrm{a}}$ \\
\hline 17 & $62 y$ & $\mathbf{M}$ & Metastatic bronchial carcinoma ${ }^{\mathfrak{c}}$ \\
\hline 18 & $62 y$ & $\mathbf{M}$ & Liver cirrhosis, myocardial infarction ${ }^{\mathrm{b}}$ \\
\hline 19 & $64 y$ & $\mathrm{~F}$ & Metastatic rectal carcinoma ${ }^{a b}$ \\
\hline 20 & $66 \mathrm{y}$ & $\mathrm{F}$ & Metastatic uterine carcinoma, pulmonary infarction \\
\hline 21 & $67 \mathrm{y}$ & $\mathrm{M}$ & Cardiac failure, liver cirrhosis, hepatoma \\
\hline 22 & $69 y$ & $\mathrm{M}$ & Cardiac failure, pulmonary infarction ${ }^{\mathrm{ac}}$ \\
\hline 23 & $72 y$ & $\mathrm{M}$ & Pulmonary tuberculosis, liver cirrhosis \\
\hline 24 & $72 y$ & M & Lung abcess, Lymphoma ${ }^{d}$ \\
\hline 25 & $80 \mathrm{y}$ & $\mathrm{F}$ & Myocardial infarction ${ }^{b}$ \\
\hline 26 & $80 \mathrm{y}$ & $F$ & Myeloblastic leukaemia \\
\hline 27 & $81 y$ & $\mathrm{~F}$ & Metastatic ovarian carcinoma ${ }^{\text {ad }}$ \\
\hline 28 & $83 y$ & $\mathrm{~F}$ & Gastric carcinoma, cardiac failure ${ }^{\mathrm{d}}$ \\
\hline 29 & $84 \mathrm{y}$ & $\mathrm{F}$ & Hypothyroidism, cardiac failure ${ }^{c d}$ \\
\hline 30 & $87 y$ & $\mathrm{~F}$ & Myocardial infarction \\
\hline
\end{tabular}

${ }^{a}$ Clinically undiagnosed pancreatitis

${ }^{b}$ Slight abnormality of glucose metabolism

${ }^{\mathrm{c}}$ Gastric or duodenal ulcer

${ }^{\mathrm{d}}$ Cholelithiasis

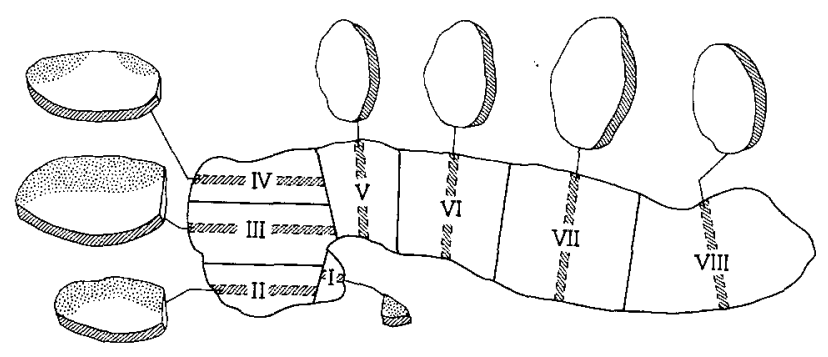

Fig. 1. Semi schematic drawing of pancreatic sampling. The pancreas cleaned from surrounding tissue was divided in eight regions (I-VIII). In the centre of each block, a $5 \mathrm{~mm}$ thick slice was cut (horizontally in regions I-IV; vertically in regions V-VIII), fixed in Bouin's fluid and embedded in paraffin. 5 um successive serial sections from each slice were then processed for immunofluorescence with anti-insulin, anti-glucagon, anti-somatostatin and antipancreatic polypeptide antisera respectively. In slices from regions I to IV, the stippled areas correspond to those rich in pancreatic polypeptide and which form together the cleavable lobe of the posterior part of the head. In our actual protocol, the attempt at detaching a posterior lobe from the pancreatic head was made before dividing the entire pancreas into the eight regions. The pancreas schematized in this figure is that shown in Figure 2
In these regions, the glucagon cells were the least frequent cell type (Table 2). In the head regions, PPrich lobules were always present in the posterior part of the sampled slices but not always in the anterior part of the same slice (see Fig. 1).

Careful observation of the $5 \mathrm{~mm}$ slices cut horizontally from regions II-IV revealed a band of connective tissue and/or adipose tissue delimiting the anterior part of the slice (blackened by the India inklatex mixture) from its posterior part. Examination of further entire pancreases showed a hitherto unnoticed lobe in the posterior part of the head. It was separated from the remainder of the gland by a plane of connective/adipose tissue, the latter allowing the posterior lobe to be removed by blunt dissection from the pancreas (Fig. $2 \mathrm{a}, \mathrm{b}$ ). The posterior lobe was always found to contain abundant PP-cells, often forming entire clusters (Fig. 2c). A section taken through region II and stained with the peroxidase-antiperoxidase method for pancreatic polypeptide shows the striking difference in PP-cell content 

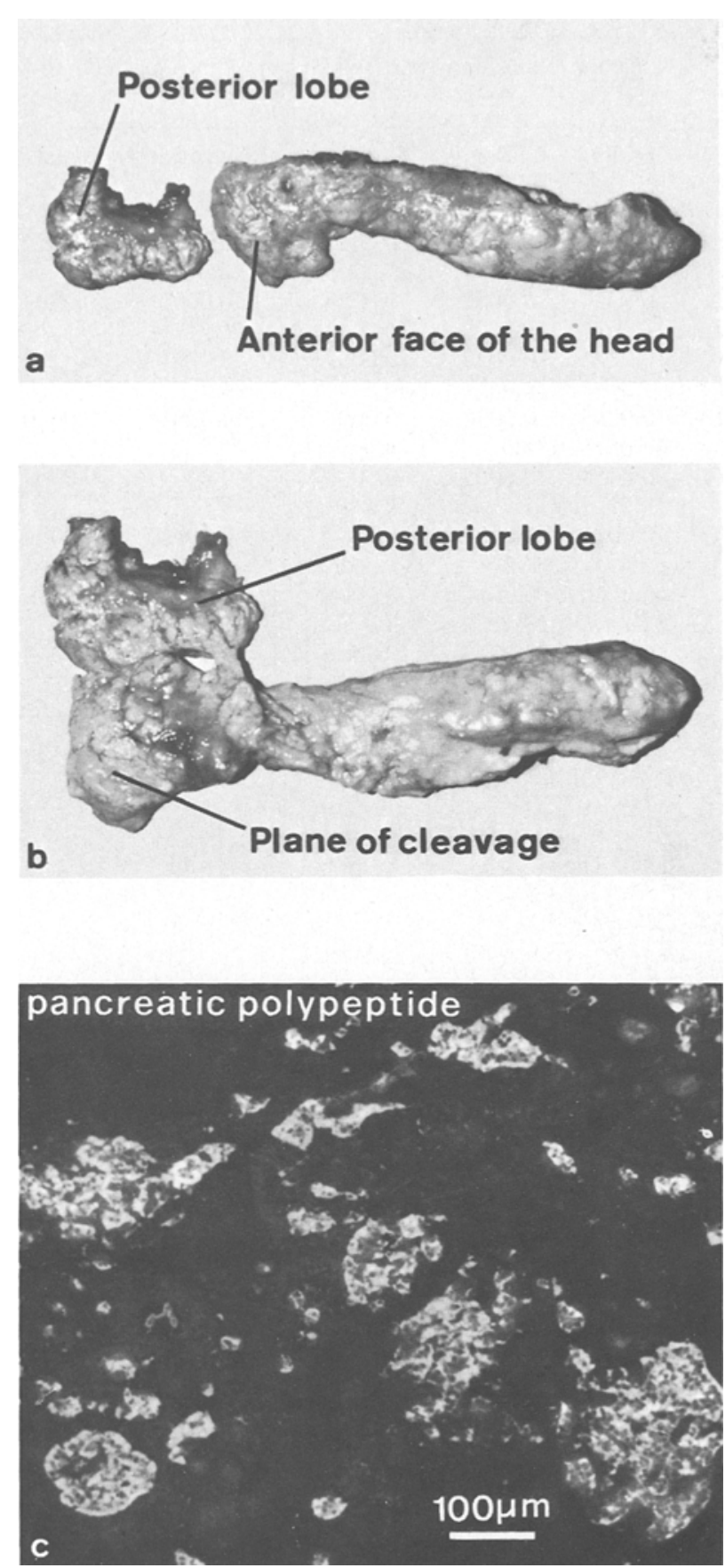

Fig. 2. a Anterior view of pancreas from case 24 from which a posterior lobe could be isolated. For photography, the posterior lobe was slid to the left. In situ, the lobe was entirely covered by the anterior face of the head (the schematic sampling of this pancreas is shown in Fig. 1). Reduced $3.1 \mathrm{X}$ from actual size. b Posterior view of the same pancreas as in a) (case 24) with the posterior lobe lifted upwards from its original position in the head. The lifting process exposes the natural plane of cleavage of this lobe from the pancreatic head. Reduced $2.3 \mathrm{X}$ from actual size. c Section from the posterior lobe stained by immunofluorescence with pancreatic polypeptide antiserum. The photographic field is crowded with fluorescent cells organized in clusters of variable sizes and shapes. Magnification X 95 between the anterior and the posterior part of the section, as well as the connective plane separating these two parts (Fig. 3).

A quantitative evaluation of insulin, glucagon, somatostatin and pancreatic polypeptide-containing cells in PP-rich and in PP-poor regions of the pancreas was carried out in 8 pancreases from subjects ranging in age from 33 foetal weeks to 80 years (Table 2). This evaluation confirmed the marked non-homogeneity of distribution of PP-cells in different parts of the pancreas. In addition, a difference in the respective proportions of endocrine cells was found between young individuals and adults. The difference affected particularly somatostatin-containing cells which were nearly 5 times more numerous in the young than in adults in all regions of the pancreas [9] (Table 2).

\section{Discussion}

Data presented above showed a marked difference in the content of pancreatic polypeptide (and glucagon) cells in different regions of the pancreas. In addition, they revealed that the proportions of pancreatic endocrine cell populations seem not to be constant throughout life. In man, as in other mammals, the pancreas develops from two primordia of the distal foregut, the ventral and dorsal pancreatic buds [10]. A recent, critical evaluation [11] favours the view that the anterior portion of the head, together with the isthmus, body and tail is derived from the dorsal component, whereas the posterior portion of the head including - when present - the omental tuberosity and the uncinate process, arises from the ventral pancreas. Our immunofluorescent data showing restriction of the $\mathrm{PP}$-rich lobules to the posterior part of the head, together with the finding of a posterior lobe in the pancreatic head separable from the remainder of the gland by a connective/adipose plane [12] contradict one of the previous concepts. This stated that "there is no remaining histological evidence to indicate that |pancreatic| parts are of different origin" [13]. Our findings are also important for the pathologist or surgeon faced with the problem of taking a pancreatic sample. While this paper was in preparation, a report of a systematic immunohistochemical and biochemical (hormone content) analysis of different portions of the human pancreas reported non-homogeneity between head and body concerning the distribution of PP and glucagon containing cells, the morphological differences being accompanied by appropriate differences in hormone content [14]. Some inconsistencies were noted however, in a few cases: PP-cells could be found by 
Table 2. Volume density of insulin-, glucagon-, somatostatin- and PP-cells in PP-rich and PP-poor pancreatic lobules of eight pancreases. The volume density was calculated according to the point counting method of Weibel [16] on immunofluorescent stained sections projected in a camera lucida. These data were used to estimate the relative proportion (in \%, italics) of each endocrine cell type

\begin{tabular}{|c|c|c|c|c|c|c|c|c|c|c|c|}
\hline \multirow[b]{2}{*}{$\begin{array}{l}\text { Case } \\
\text { no. }\end{array}$} & \multirow[b]{2}{*}{ Age } & \multicolumn{5}{|c|}{$\begin{array}{l}\text { PP-rich lobules (posterior part of slices in at least } \\
\text { two of regions I-IV) }\end{array}$} & \multicolumn{5}{|c|}{ PP-poor lobules (any part of slices in regions V-VIII) } \\
\hline & & $\begin{array}{l}\text { Insulin } \\
\text { cells }\end{array}$ & $\begin{array}{l}\text { Glucagon } \\
\text { cells }\end{array}$ & $\begin{array}{l}\text { Somatostatin } \\
\text { cells }\end{array}$ & PP cells & Total & $\begin{array}{l}\text { Insulin } \\
\text { cells }\end{array}$ & $\begin{array}{l}\text { Glucagon } \\
\text { cells }\end{array}$ & $\begin{array}{l}\text { Somatostatin } \\
\text { cells }\end{array}$ & PP cells & Total \\
\hline \multirow[t]{2}{*}{3} & foetus & 0.0126 & 0.0003 & 0.0096 & 0.0170 & 0.0395 & 0.0156 & 0.0047 & 0.0122 & 0.0002 & 0.0327 \\
\hline & $33 w$ & 31.9 & 0.8 & 24.3 & 43.0 & & 47.7 & 14.4 & 37.3 & 0.6 & \\
\hline \multirow[t]{2}{*}{5} & $3 w$ & 0.0173 & 0.0005 & 0.0106 & 0.0308 & 0.0592 & 0.0360 & 0.0087 & 0.0258 & 0.0002 & 0.0707 \\
\hline & & 29.2 & 0.8 & 18.0 & 52.0 & & 50.9 & 12.3 & 36.5 & 0.3 & \\
\hline \multirow[t]{2}{*}{6} & $5 \mathrm{~m}$ & 0.0057 & 0.0003 & 0.0051 & 0.0189 & 0.0300 & 0.0121 & 0.0042 & 0.0093 & $<0.0001$ & 0.0256 \\
\hline & & 19.0 & 1.0 & 17.0 & 63.0 & & 47.2 & 16.4 & 36.3 & 0.1 & \\
\hline \multirow[t]{2}{*}{7} & $9 y$ & 0.0023 & 0.0001 & 0.0004 & 0.0235 & 0.0268 & 0.0046 & 0.0010 & 0.0004 & $<0.0001$ & 0.0060 \\
\hline & & 10.4 & 0.4 & 1.5 & 87.7 & & 76.6 & 16.6 & 6.6 & 0.3 & \\
\hline \multirow[t]{2}{*}{9} & $29 y$ & 0.0023 & 0.0001 & 0.0003 & 0.0170 & 0.0197 & 0.0058 & 0.0008 & 0.0003 & $<0.0001$ & 0.0069 \\
\hline & & 11.7 & 0.5 & 1.5 & 86.3 & & 84.0 & 11.5 & 4.3 & 0.6 & \\
\hline \multirow[t]{2}{*}{11} & $45 y$ & 0.0024 & 0.0002 & 0.0003 & 0.0162 & 0.0191 & 0.0068 & 0.0009 & 0.0002 & 0.0002 & 0.0081 \\
\hline & & 12.6 & 1.1 & 1.5 & 84.8 & & 83.9 & 11.1 & 2.5 & 2.5 & \\
\hline \multirow[t]{2}{*}{20} & $66 y$ & 0.0069 & 0.0001 & 0.0005 & 0.0240 & 0.0315 & 0.0126 & 0.0016 & 0.0005 & 0.0001 & 0.0148 \\
\hline & & 21.9 & 0.3 & 1.6 & 76.2 & & 85.1 & 10.8 & 3.4 & 0.7 & \\
\hline \multirow[t]{2}{*}{26} & $80 y$ & 0.0015 & 0.0001 & 0.0003 & 0.0151 & 0.0170 & 0.0044 & 0.0015 & 0.0003 & 0.0001 & 0.0063 \\
\hline & & 8.8 & 0.6 & 1.8 & 88.8 & & 69.8 & 23.8 & 4.8 & 1.6 & \\
\hline
\end{tabular}

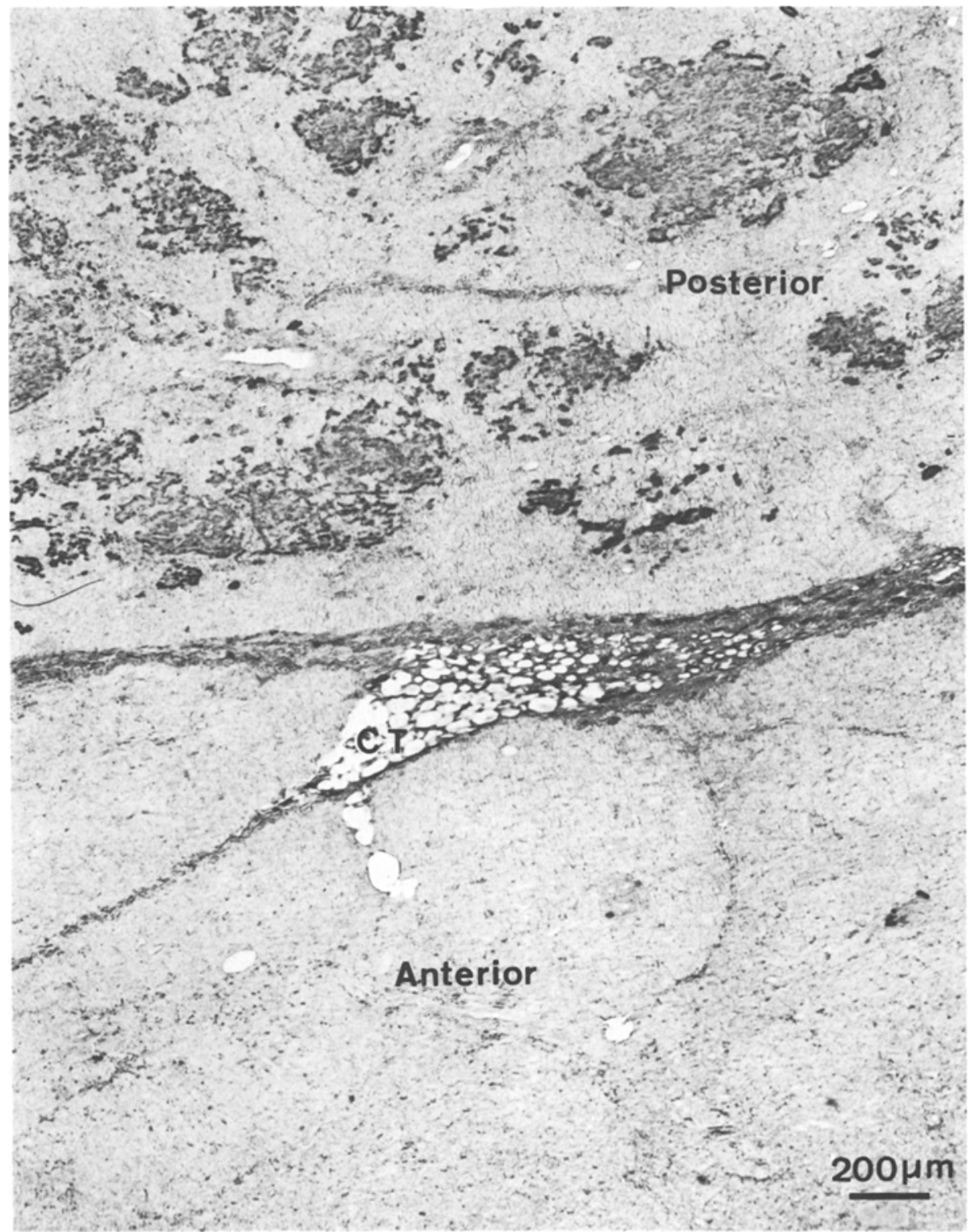

Fig. 3. Section made in region III (head) (see Fig. 1) of the pancreas of case 23. The section was immunostained for pancreatic polypeptide with the peroxidase-antiperoxidase method (the reaction product is black). This photographic field shows the band of connective tissue (CT) separating an anterior from a posterior part in the pancreatic head. The connective plane allowed a posterior lobe to be isolated. Note that virtually all pancreatic polypeptide cells were situated in the posterior region. Magnification X 50 
immunofluorescence while pancreatic polypeptide was not detected by radioimmunoassay (or the reverse). In view of the marked anterior-posterior non-homogeneity of PP-cell content observed in a same horizontal section of the head, such inconsistencies may well be explained if, for example, the anterior part of the head sample was assayed for immunofluorescence while the posterior part of the same sample was used for radioimmunoassay (or the reverse). If results from different laboratories are to be compared, a unified sampling method, emphasizing the exact territory of the pancreas studied, as well as a sensitive quantitative analysis of the endocrine cell populations are thus now in order. Although based on a wide age range with only one individual in each class (this sampling was dictated by the availability of human material at the necropsy room), our data suggests that the proportions of each endocrine cell populations in the islets are not constant throughout life. If confirmed by study of a larger number of cases, this finding will raise interesting questions concerning the intra islet regulation of secretory output according to the hypothesis of interaction of one cell population on its neighbour [15].

Acknowledgements. This work was presented at a NIH workshop on diabetes and obesity, Phoenix, Arizona, November 17-19, 1978.

The work was supported by grant nr 3.120 .77 from the Swiss National Science Foundation and by grant nr N01-AM-7-2213 (Human diabetes program Phoenix) from the National Institutes of Health, USA. The technical assistance of I. Bernard, M. Eissler, A. M. Lucini, I. Fuglister, D. Mottier, M. Sarteur and M. Sidler is gratefully acknowledged. We thank Dr. R. A. Donald, Dr. R. E. Chance, Dr. S. Ito and Dr. P. H. Wright, for supplying antibodies.

\section{References}

1. Larsson, L.-I., Sundler, F., Håkanson, R.: Pancreatic polypeptide - a postulated new hormone: identification of its cellular storage site by light and electron microscopic immunocytochemistry. Diabetologia 12, 211-226 (1976)

2. Orci, L., Baetens, D., Ravazzola, M., Stefan, Y., MalaisseLagae, F.: Ilots à polypeptide pancréatique (PP) et îlots à glucagon: distribution topographique distincte dans le pancréas de Rat. C. R. Acad. Sci. [D] (Paris) 283, 1213-1216 (1976)
3. Orci, L., Baetens, D., Ravazzola, M., Stefan, Y., MalaisseLagae, F.: Pancreatic polypeptide and glucagon: Non-random distribution in pancreatic islets. Life Sci. 19, 1811-1816 (1976)

4. Gepts, W., De Mey, J., Marichal-Pipeleers, M.: Hyperplasia of "pancreatic polypeptide"-cells in the pancreas of juvenile diabetics. Diabetologia 13, 27-34 (1977)

5. Klöppel, G., Bommer, G., Commandeur, G., Heitz, Ph.: The endocrine pancreas in chronic pancreatitis. Immunocytochemical and ultrastructural studies. Virchows Arch. [Pathol. Anat.] 377, 157-174 (1978)

6. Orci, L., Malaisse-Lagae, F., Baetens, D., Perrelet, A.: Pancreatic-polypeptide-rich regions in human pancreas. Lancet 1978 II, 1200-1201

7. Coons, A. H., Leduc, E. H., Connolly, J. M.: Studies on antibody production. I. A method for the histochemical demonstration of specific antibody and its application to a study of the hyperimmune rabbit. J. Exp. Med. 102, 49-63 (1955)

8. Sternberger, L. A., Hardy, P.H., Jr., Cuculis, J. J., Meyer, H. G.: The unlabeled antibody enzyme method of immunohistochemistry. Preparation and properties of a soluble antigenantibody complex (horseradish peroxidase-antihorseradish peroxidase) and its use in identification of spirochetes. J. Histochem. Cytochem. 18, 315-333 (1970)

9. Orci, L., Stefan, Y., Malaisse-Lagae, F., Perrelet, A.: Instability of pancreatic endocrine cell populations throughout life. Lancet 1979 I, 615-616

10. Delmas, A.: Les ébauches pancréatiques dorsales et ventrales. Leurs rapports dans la constitution du pancréas définitif. Ann. Anat. Pathol. [Paris] 16, 253-266 (1939)

11. O'Rahilly, R., Müller, F.: A model of the pancreas to illustrate its development. Acta Anat. (Basel) 100, 380-385 (1978)

12. Malaisse-Lagae, F., Orci, L., Perrelet, A.: Anatomic and hormonal markers for the ventral primordium in the human pancreas? N. Engl. J. Med. 300, 436 (1979)

13. Liu, H. M., Potter, E. L.: Development of the human pancreas. Arch. Pathol. 74, 439-452 (1972)

14. Gersell, D. J., Gingerich, R. L., Greider, M. H.: Regional distribution and concentration of pancreatic polypeptide in the human and canine pancreas. Diabetes 28, 11-15 (1979)

15. Orci, L., Unger, R. H.: Functional subdivision of islet of Langerhans and possible role of D-cells. Lancet 1975 II, $1243-1246$

16. Weibel, E. R.: Stereological principles for morphometry in electron microscopic cytology. Int. Rev. Cytol. 26, 235-302 (1969)

Received: May, 2, 1979,

and in revised form: July 4, 1979

L. Orci

Institute of Histology and Embryology

University of Geneva Medical School

CH-1211 Geneva 4

Switzerland 